\title{
THIRTEEN-YEAR FOLLOW UP OF A CONSERVATIVE APPROACH FOR CLOSING DIASTEMA IN ANTERIOR TEETH WITH COMPOSITE RESIN
}

\author{
TREZE ANOS DE ACOMPANHAMENTO CLÍNICO DE RESTAURAÇÕES \\ CONSERVATIVAS DE RESINA COMPOSTA NO FECHAMENTO DE DIASTEMAS \\ ANTERIORES
}

\author{
Flavia Pardo Salata NAHSAN ${ }^{1}$; Vera Lucia SCHMIT ${ }^{2}$; Fabiana Scarparo NAUFEL ${ }^{3}$; \\ André Luis FARIA-E-SILVA ${ }^{4}$; Larissa Pinceli CHAVES ${ }^{5}$ \\ 1. Adjunct Professor, Federal University of Sergipe, Aracaju, SE, Brazil. flavia_odonto@ hotmail.com;. 2. Adjunct Professor \\ Department of Restorative Dentistry, Parana West State University, Cascavel, PR, Brazil; 3. Associated Professor Department of \\ Restorative Dentistry, Parana West State University, Cascavel, PR, Brazil; 4. Adjunct Professor, Federal University of Sergipe, Aracaju, \\ SE, Brazil; 5. Phd Student, Department of Operative Dentistry, Endodontics and Dental Materials. Bauru School of Dentistry, \\ University of São Paulo, Bauru, SP, Brazil
}

\begin{abstract}
Anterior multiple diastema is a problem when the objective is harmonic an smile. Composite resin direct adhesive restorations provide satisfactory esthetic and function with minimum wear of the dental structures. The treatment success depends mainly on good patient oral health, correct diagnosis and technique. This article describes the step by step of an multiple anterior diastema restoration by using composite resin to mimic the enamel and dentin, improving the smile's esthetic. This 13-year follow up shows imperceptible restorations that maintain the natural reproduction of the dental structures over the long term.
\end{abstract}

KEYWORDS: Dental esthetic. Diastema. Composite resins.

\section{INTRODUCTION}

Among the treatment options for anterior diastema, the orthodontics (DE ARAUJO et al., 2009) composite direct resin and ceramic materials are the alternatives most commonly used currently for the esthetic and rehabilitative treatment of anterior teeth affected with diastema due to the evolution of these materials (DE ARAUJO et al., 2009; WOLFF et al., 2010). This treatment results in improved esthetic and mechanical properties. In cases of diastemas located at one or both sides of the tooth, the main challenges are to reestablish a proper interproximal contact, with the interdental papilla filling the space underneath the contact area (LENHARD, 2008), and to obtain color, anatomic shape and function. However, obtaining harmonic and imperceptible long-term restorations requires certain patient conditions (HEINTZE et al., 2015).

Higher longevity of restoration is observed mainly in patients presenting with sound teeth, proper occlusion and good oral health (FRESE et al., 2013). In addition to restorations with extended longevity, preservation of the dental hard tissues and low cost procedures are required by patients. Combined to these factors, the periodic recall to the dentist for restorations evaluation, refinishing and repolishing may be necessary in many cases.

Thus, this case report outlines a simple and effective technique for anterior diastema closure with composite resin and identifies the required clinical strategies needed to obtain esthetics and longevity in restorations.

\section{Case report}

A 20-year-old female patient, a graduate student of dentistry in Parana West State University, complained about the appearance of her smile. After an accurate medical story, the clinical examination revealed a moderate diastema between the upper incisor teeth (Figure 1). As one of the most common dental problems in today's clinics are poor oral health and wear, specifically when related to bruxism (PONTONS-MELO et al., 2011), to restore the diastema with composite resin, the patient should present a good oral health, no plaque retention and a proper occlusion. The use of direct composite resin restorations was choiced, due to its low cost, fasten outcome and esthetics.

Isolation was performed using a rubber dam, and the surfaces of the teeth were coarsened using diamond ultrafine burs (Figure 2). The surfaces of the teeth were then etched with $37 \%$ phosphoric acid applied for $30 \mathrm{~s}$ to the enamel, rinsed with an air-water spray for $60 \mathrm{~s}$ and dried with an air-stream. The adhesive system (Excite, Vivadent) was applied in two consecutive layers, the solvent was evaporated, and the adhesive was lightcured for $40 \mathrm{~s}$. 


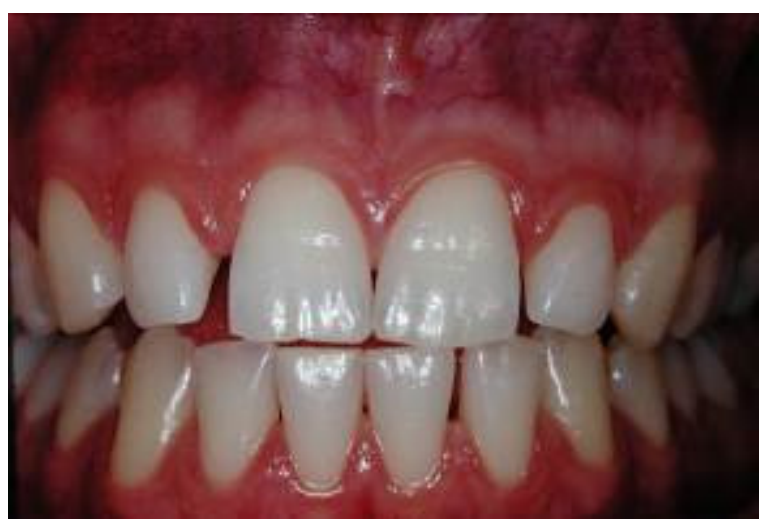

Figure 1. Initial case, showing the aspects of tooth with diastema.

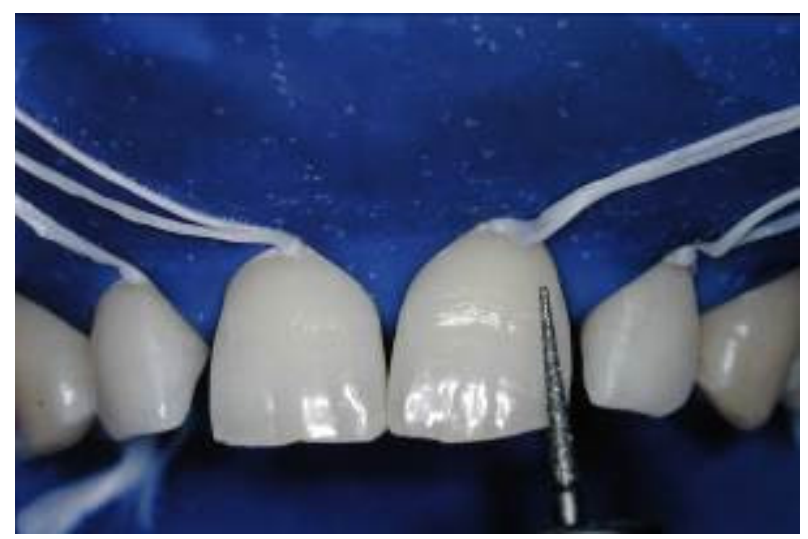

Figure 2. Using the ultrafine diamond bur to prepare the enamel tissue.

A personalized silicon guide was positioned in the teeth, and the artificial palatal enamel, proximal and incisal faces, corresponding to enamel, were performed using a micro-hybrid composite resin (Filtek Z-250, shade A2) (Figure 3). The incisal (Filtek Z-250) and B2 dentin (Tetric Ceram) shades were inserted to reproduce the incisal

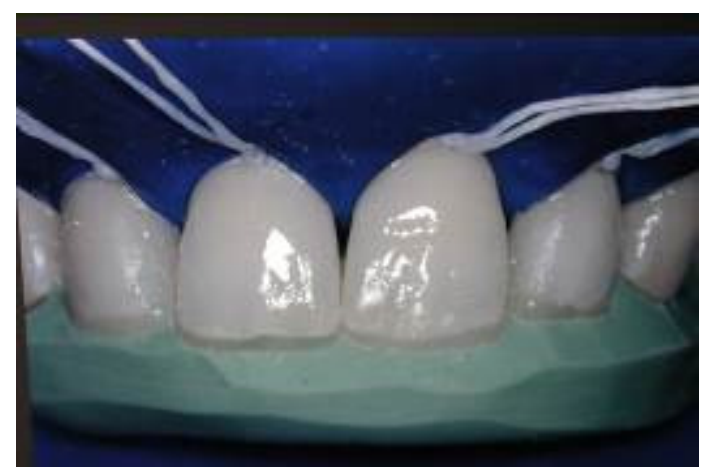

Figure 3. Artificial palatal enamel made using a personalized silicon guide. translucency and the opalescent halo, respectively. The shade A2 dentin (Filtek Z-250) was used to reproduce the dentin tissue. The restoration build-up was finalized with a micro-filled resin inserted in one single increment to minimize the occurrence of bonded lines on the vestibular face (Figure 4).

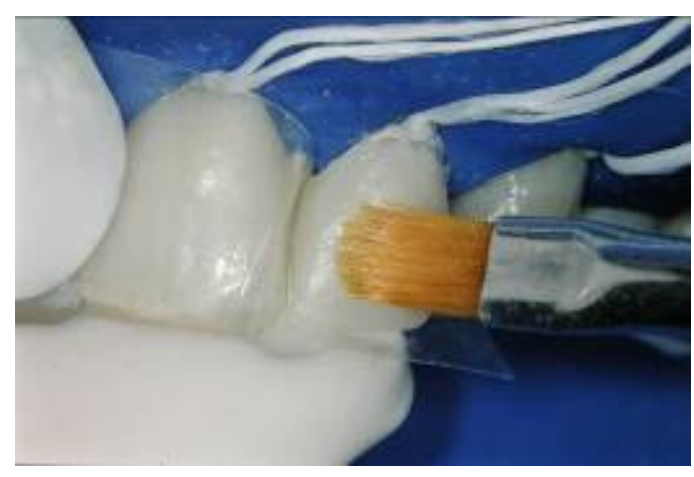

Figure 4. Application of last composite resin layer over the other shades, reproducing the buccal enamel. 
After one week, the finishing and polishing procedures were performed to obtain anatomic and morphological details using abrasive discs and a felt

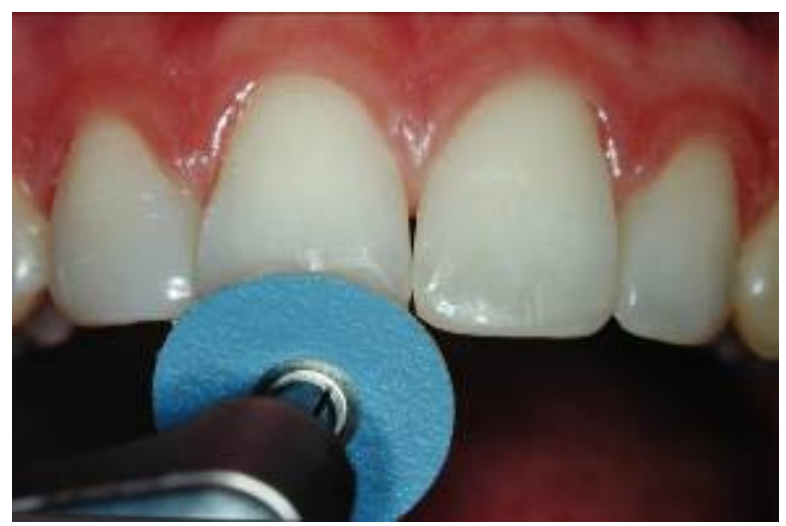

Figure 5. Finishing and polishing system.

The patient returned for re-evaluation after eight years, and the re-polishing procedure was performed. The follow-up of 13 years showed disc in conjunction with diamond polishing paste (Figures 5 and 6).

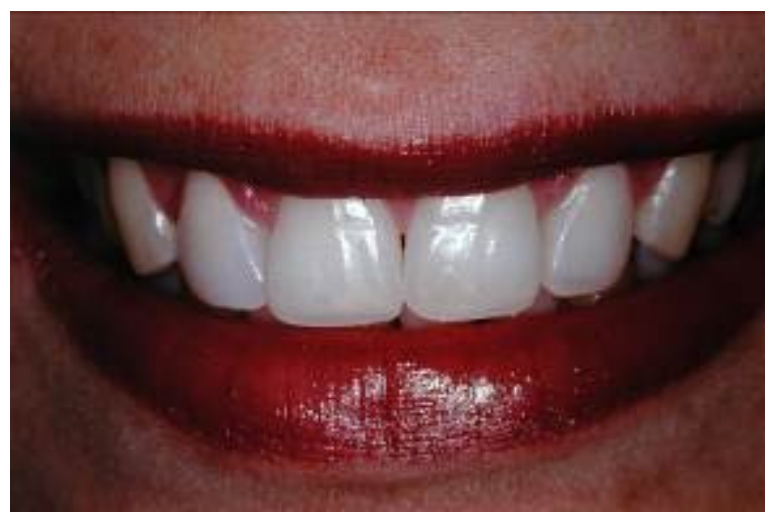

Figure 6. Final esthetic outcome.

clinical performance of the resin composite restoration and the color stability of the material, with satisfactory results still observed (Figure 7).

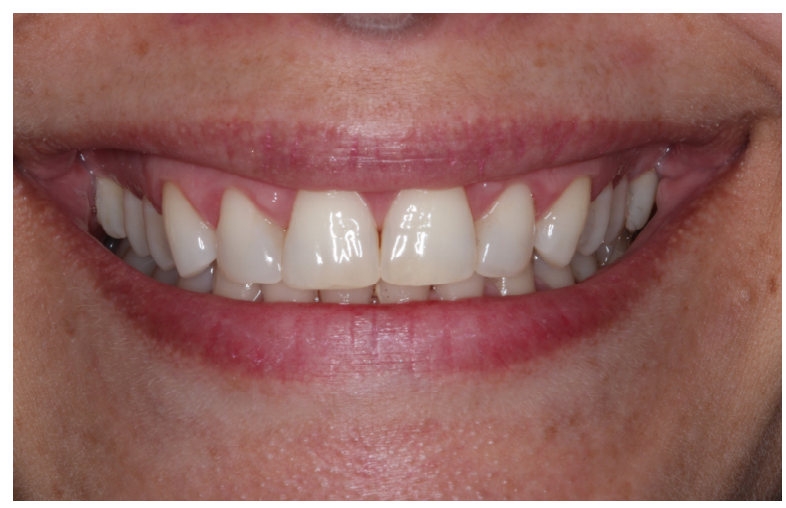

Figure 7. Follow up of 13 years.

\section{DISCUSSION}

In many cases, the use of Orthodontics are required for closing diastema spaces, associated or not to composite resin or ceramic restorations. However, orthodontics are more longer, expensive and complex treatment which requires the use of fixed appliances (DE ARAUJO et al., 2009. Prosthodontics do not preserve the hard dental tissues, besides requires laborial steps (DE ARAUJO et al., 2009 presenting also higher costs.

When the outcome required is immediate and the distance between the teeth are suitable, the use of restorations with minimal intervation are a good option. The clinical composite resin restorations longevity has been related. Even although in the compromised enamel with amelogenesis imperfecta, Gerdolle et al., 2015, showed reliable approach direct adhesive composite resin restoration even after 5 years of function. Also, posterior restorations has been evaluated. Composite mycrohybrid composite resins showed a survival rate of $97,8 \%$ in classe II restorations, showing a acceptable clinical durability (LEMPEL et al., 2015). Al-Khayatt et al., 2013, showed and approximate survival of $85 \%$ in direct composite resin restorations bonded to the worn anterior dentition at the 7-year follow-up. Regardless of no clinical randomized studies or case reports which shows the good performance of composite resin specifically in diastemas closuring has been related, the material evaluated is the same.

Refinishing and repolishing can be required to maintain the esthetic and pleasant smile. Nevertheless, sometimes the minimal repair intervation with a new application of composite resin is needed, as showed Francisconi et al., 2012 in a 9-years follow-up case report. In this case 
report, the patient had a good oral health and proper occlusion, and no intervention was applyed.

Despite the increased longevity, composite restorations seal the cavity and prevent retentive plaque areas to avoid pain and allow the patient to maintain adequate oral health. However, resin restorations, despite their good attributes, may present with_discoloration, loss of the form/wear in cases of malocclusion, fractures and marginal degradation.

These restorative treatment problems cannot be avoided, but controlling the diet and therapeutic fluoride use, maintaining dental plaque at low levels, refinishing and repolishing of the restorations and periodic control visits to the dentist can certainly extend the long-term restoration. Informing patients precisely of the longevity of these restorations is difficult (PEUMANS et. al., 1997), but it is necessary that they be informed about this matter.

Technological improvements have occurred in response to the growing societal demand on clinicians regarding aesthetics and for materials with optical characteristics similar to those of the natural dental element. Recent composite resins display an expressive variety of colors and effects, which facilitate different combinations of translucence and opacity. Moreover, composite resins are easier to manipulate and insert, facilitate the sculpture of the dental anatomy, presents low cost (SUNDFELD et al., 2012) and minimal hard tissue intervation preserving the tooth.

Because of these improvements, interventions with composite resins have made possible the reestablishment of specific and individual details existing in the natural dentition in a satisfactorily aesthetic way (NAHSAN et al, 2012).

The use of ceramic fragments has been reported in the literature; however, more scientific studies are necessary to verify the long-term success of their use (OKIDA et al, 2012). Composite resins occupy a paramount position among restorative materials for anterior teeth because they offer good predictability, acceptable longevity, and the possibility of more conservative procedures at a lower cost than indirect restorations (PONTONSMELO et al., 2011).

\section{CONCLUSION}

After the establishment of a correct diagnosis, the resin-based restorations are valuable esthetic procedures that allow greater durability with easy, safe and conservative approaches.

RESUMO: Diastemas anteriores múltiplos podem representar um problema na estética quando o objetivo é um sorriso harmonico. Restaurações de resina composta aplicadas de forma direta promovem função e estética satisfatórias, com o mínimo de desgaste da estrutura dental. O tratamento depende principalmente da boa higiene oral, de um correto diagnóstico e da técnica empregada. Este artigo descreve os passos de restaurar diastemas anteriores usando resinas compostas para mimetizar o esmalte e a dentina, otimizando a estética do sorriso. Este acompanhamento clínico de 13 anos demonstra as restaurações imperceptíveis que mantiveram a reprodução natural das estruturas dentárias ao longo do tempo.

PALAVRAS-CHAVE: Estética dentária. Diastemas. Resinas compostas.

\section{REFERENCES}

AL-KHAYATT, A. S.; RAY-CHAUDHURI, A.; POYSER, N. J.; BRIGGS, P. F.; PORTER, R. W.; KELLEHER, M. G.; ELIYAS, S. Direct composite restorations for the worn mandibular anterior dentition: a 7-year follow-up of a prospective randomised controlled split-mouth clinical trial. J Oral Rehabil. Malden, v. 40, n. 5,p. 389-401, 2013. http://dx.doi.org/10.1111/joor.12042

DE ARAUJO, E. M. JR.; FORTKAMP, S.; BARATIERI, L. N. Closure of diastema and gingival recontouring using direct adhesive restorations: a case report. J Esthet Restor Dent, London, v. 21, n. 4, p. 229-40, 2009. http://dx.doi.org/10.1111/j.1708-8240.2009.00267.x

FRANCISCONI, L. F.; FREITAS, M. C.; OLTRAMARI-NAVARRO, P. V.; LOPES, L. G.; FRANCISCONI, P. A.; MONDELLI, R. F. Multidisciplinary approach to the establishment and maintenance of an esthetic smile: a 9-year follow-up case report. Quintessence Int. Berlin, v. 43, n. 10, p. 853-8, 2012. 
FRESE, C.; SCHILLER, P.; STAEHLE, H.J.; WOLFF, D. Recontouring teeth and closing diastemas with direct composite buildups: a 5-year follow-up. J Dent, Bristol, v. 41, n. 11, p. 979-85, 2013.

http://dx.doi.org/10.1016/j.jdent.2013.08.009

GERDOLLE, D.; MORTIER, E.; RICHARD, A.; VAILATI, F. Full-mouth adhesive rehabilitation in a case of amelogenesis imperfecta: a 5-year follow-up case report. Int J Esthet Dent. Berlin, v. 10, n. 1, p. 12-31, 2015.

HEINTZE, S. D.; ROUSSON, V.; HICKEL, R. Clinical effectiveness of direct anterior restorations-A metaanalysis. Dent Mater. Kidlington, v. 31, n. 5, p. 481-495, 2015. http://dx.doi.org/10.1016/j.dental.2015.01.015

LEMPEL, E.; TÓTH, Á.; FÁBIÁN, T.; KRAJCZÁR, K.; SZALMA, J.Retrospective evaluation of posterior direct composite restorations: 10-year findings. Dent Mater. Kidlington, v. 31, n. 2, p. 115-22, 2015. http://dx.doi.org/10.1016/j.dental.2014.11.001

LENHARD, M. Closing diastemas with resin composite restorations. Eur J Esthet Dent. Berlin, v. 3, n. 3, p. 258-68, 2008.

NAHSAN, F. P; MONDELLI, R. F.; FRANCO, E. B.; NAUFEL, F. S.; UEDA, J. K.; SCHMITT, V. L.; BASEGGIO, W. Clinical strategies for esthetic excellence in anterior tooth restorations: understanding color and composite resin selection. J Appl Oral Sci. Bauru, v. 20, n. 2, p. 151-6. Mar-Apr, 2012. http://dx.doi.org/10.1590/S1678-77572012000200005

OKIDA, R. C.; FILHO, A. J.; BARAO, V. A.; DOS SANTOS, D. M.; GOIATO, M. C. The use of fragments of thin veneers as a restorative therapy for anterior teeth disharmony: a case report with 3 years of follow-up. $\mathbf{J}$ Contemp Dent Pract, New Delhi, v. 13, n. 3, p. 416-20. May, 2012.

PEUMANS, M.; VAN MEERBEEK, B.; LAMBRECHTS, P.; VANHERLE, G. The 5-year clinical performance of direct composite additions to correct tooth form and position. I. Esthetic qualities. Clin Oral Investig. Berlin, v. 1, n. 1, p. 12-8. Feb, 1997. http://dx.doi.org/10.1007/s007840050003

PONTONS-MELO, J. C.; FURUSE, A. Y.; MONDELLI, J. A direct composite resin stratification technique for restoration of the smile. Quintessence Int. Berlin, v. 42, n. 3, p. 205-11, 2011.

SUNDFELD, R. H.; MACHADO, L. S.; DE OLIVEIRA, F. G.; SANTOS, E. A.; LUGATO, I. C.;

SUNDFELD, NETO D. Conservative reconstruction of the smile by orthodontic, bleaching, and restorative procedures. Eur J Dent. Mumbai, v. 6, n. 1,p. 105-9, 2012.

WOLFF, D.; KRAUS, T.; SCHACH, C.; PRITSCH, M.; MENTE, J.; STAEHLE, H. J.; DING, P. Recontouring teeth and closing diastemas with direct composite buildups: a clinical evaluation of survival and quality parameters. J Dent. Bristol, n. 38, v. 12, p. 1001-9, 2010. http://dx.doi.org/10.1016/j.jdent.2010.08.017 